\section{Using Color Infrared Imagery to Detect Sooty Mold and Fungal Pathogens of Glasshouse-propagated Plants}

\author{
Kenneth R. Summy ${ }^{1}$ \\ Department of Biology, The University of Texas-Pan American, Edinburg, \\ TX 78541
}

\section{Christopher R. Little ${ }^{2,3}$}

Department of Plant Pathology, Kansas State University, 4024 Throckmorton Plant Sciences Center, Manhattan, KS 66506-5502

\begin{abstract}
Additional index words. spectroradiometer, color infrared (CIR) imagery, simple vegetation index, citrus (Citrus spp.), sooty mold (Capnodium spp.), greasy spot (Mycosphaerella citri), powdery mildew (Sphaerotheca fuliginea)
\end{abstract}

\begin{abstract}
Fungi are major biotic constraints for optimum production and quality of glasshouse plants. When plants are infested with sooty mold (Capnodium spp.) or infected with pathogens, the reflected wavelengths of the electromagnetic spectrum are altered. Spectroradiometric measurements and color infrared (CIR) images of control, honeydew-coated, and sooty mold-infested saplings and individual leaves from trifoliate orange (Poncirus trifoliata), sour orange (Citrus aurantium), 'Valencia' orange (C. sinensis), and 'Bo' tree (Ficus religiosa) were obtained. Grapefruit saplings and individual leaves infected with Mycosphaerella citri (greasy spot) were imaged under glasshouse conditions. Similarly, muskmelon foliage showing low and high levels of powdery mildew (Sphaerotheca fuliginea) disease severity were analyzed. When examining individual leaves, all fungal biotic stressors generally resulted in variable spectral reflectance data, especially in the blue $(450 \mathrm{~nm})$ and green $(550 \mathrm{~nm})$ wavelengths; however, values in the red $(650 \mathrm{~nm})$ tended to increase and values in the near-IR $(850 \mathrm{~nm})$ tended to decrease with stress. Near-IR/red image ratios were significantly reduced $(P<0.05)$ in stressed whole plant foliage and individual leaves relative to healthy controls. The accumulation of insect honeydew (which occurs before sooty mold infestation) significantly increased $(P<0.05)$ near-IR reflectance values and near-IR/red ratios in 'Valencia' orange and near-IR/ratios in 'Bo' tree foliage and individual leaves. Image acquisition and enhancement techniques may prove useful in large-scale production greenhouses where existing infrastructure and high plant populations require high throughput data analysis and identification of biotic stressors.
\end{abstract}

Remote sensing has been used for the last several decades to detect both abiotic and biotic stressors affecting agricultural crops. Studies have traditionally focused on aerial image acquisition using color infrared (CIR) photography of plant stress, including salinity problems (Everitt et al., 1981; Myers et al., 1963), nutrient deficiencies (Thomas

\footnotetext{
Received for publication 25 Oct. 2007. Accepted for publication 16 Jan. 2008.

This paper is Contribution No. 08-214-J from the Kansas Agricultural Experiment Station, Manhattan. We thank Vic French (entomologist) and Mani Skaria (plant pathologist) of the Texas A\&M Kingsville-Citrus Center and Kevin Crosby (vegetable breeder) of the Texas A\&M Agricultural Experiment Station (Weslaco, TX) for access to glasshouse crops.

${ }^{1}$ Associate Professor of Biology, Remote Sensing and Entomology.

${ }^{2}$ Assistant Professor of Plant Pathology, Row Crops Pathology.

${ }^{3}$ To whom reprint requests should be addressed; e-mail crlittle@ksu.edu
}

and Oerther, 1977), insect predation (Blazquez et al., 1988; Everitt et al., 1994; Hart et al., 1973; Hart and Myers, 1968), and pathogens (Brenchley, 1964; Colwell, 1956; Norman and Fritz, 1965; Payne et al., 1971; Toler et al., 1981; Yang et al., 2005). However, only recently have researchers begun to consider the potential application of a traditionally "outdoor" technology for the indoor glasshouse environment. In addition, because CIR images can be subdivided into three separate wavebands [green (500 to $600 \mathrm{~nm})$, red (600 to $700 \mathrm{~nm}$ ), and near-IR (NIR; 700 to $1100 \mathrm{~nm})$ ], the use of image enhancement techniques that rely on these, such as unsupervised/supervised image classification and image ratios [such as the simple vegetation index (NIR/red)], have proven to be reliable approaches for improving the data acquired from CIR images and their subsequent interpretation (Little et al., 2005; Summy and Little, 2005; Summy et al., 2003, 2004, 2005; Yousef et al., 2005).

Sooty mold (Figs. 1B and 1E) is a common problem in which excessive insect feeding activities occur. The condition results from honeydew deposition (Fig. 1D) by insects such as whiteflies (Hemiptera: Aleyrodidae), aphids (Hemiptera: Aphididae), and mealy bugs (Hemiptera: Pseudococcidae) (Drees and Jackman, 1998). All of these insect groups are common in the glasshouse; however, specific examples differ depending on plant host and geographic location. Ultimately, all of these insects are capable of producing large amounts of honeydew excretions. These excretions are composed of numerous sugars capable of supporting sooty mold growth, which consists primarily of Capnodium and related fungal species (Farr et al., 1989; Reynolds, 1999).

In addition to sooty mold accumulation, there are a myriad of fungal leaf spots that occur on glasshouse plant foliage and it would be impossible to investigate all of them here. For reviews of leaf spot diseases of ornamentals, flowering potted plants, tomatoes, citrus, and cucurbits, see Chase (1987), Daughtrey et al. (1995), Jones et al. (1991), Timmer et al. (2000), and Zitter et al. (1996), respectively. Most of the common leaf spots will cause significant tissue chlorosis that either surrounds the necrotic lesions or extends throughout the affected foliage. In the present study, citrus plants that were propagated under glasshouse conditions were infected by Mycosphaerella citri, an ascomycete causing "greasy spot" (Fig. 1G) (Farr et al., 1989; Timmer et al., 2000). This disease produces characteristic black fruiting structures (pseudothecia) in leaf tissues, whole leaves become chlorotic, and defoliation of saplings or plant grafts can be common.

Powdery mildews are caused by cleistothecial ascomycetes and are characterized by the profuse production of conidia, conidiophores, and hyphae that appear white on the upper surface of plant leaves (Fig. 1I). The primary examples of fungal species causing powdery mildews of dicot hosts in greenhouses include Erysiphe cichoracearum (cucurbits and many flowers), E. polygonii (numerous vegetables and hydrangeas), and Sphaerotheca fuliginea (cucurbits; discussed in this study) (Farr et al., 1989; Texas Agricultural Experiment Station, 1988).

The purpose of this study was to acquire spectral reflectance data and CIR imagery from plants produced under glasshouse conditions and affected by the following fungal stressors: 1) sooty mold infestation, 2) a foliar leaf spot disease accompanied by extensive tissue chlorosis, and 3 ) a powdery mildew disease. Additionally, CIR image wavebands were used to construct NIR/red derivative image ratios to facilitate interpretation of treatment differences.

\section{Materials and Methods}

Plant propagation and fungal stressors. Trifoliate orange (Poncirus trifoliata), 'Valencia' orange (Citrus sinensis), sour orange (C. aurantium), grapefruit (C. paradisi), and 'Bo' tree (Ficus religiosa) plants 

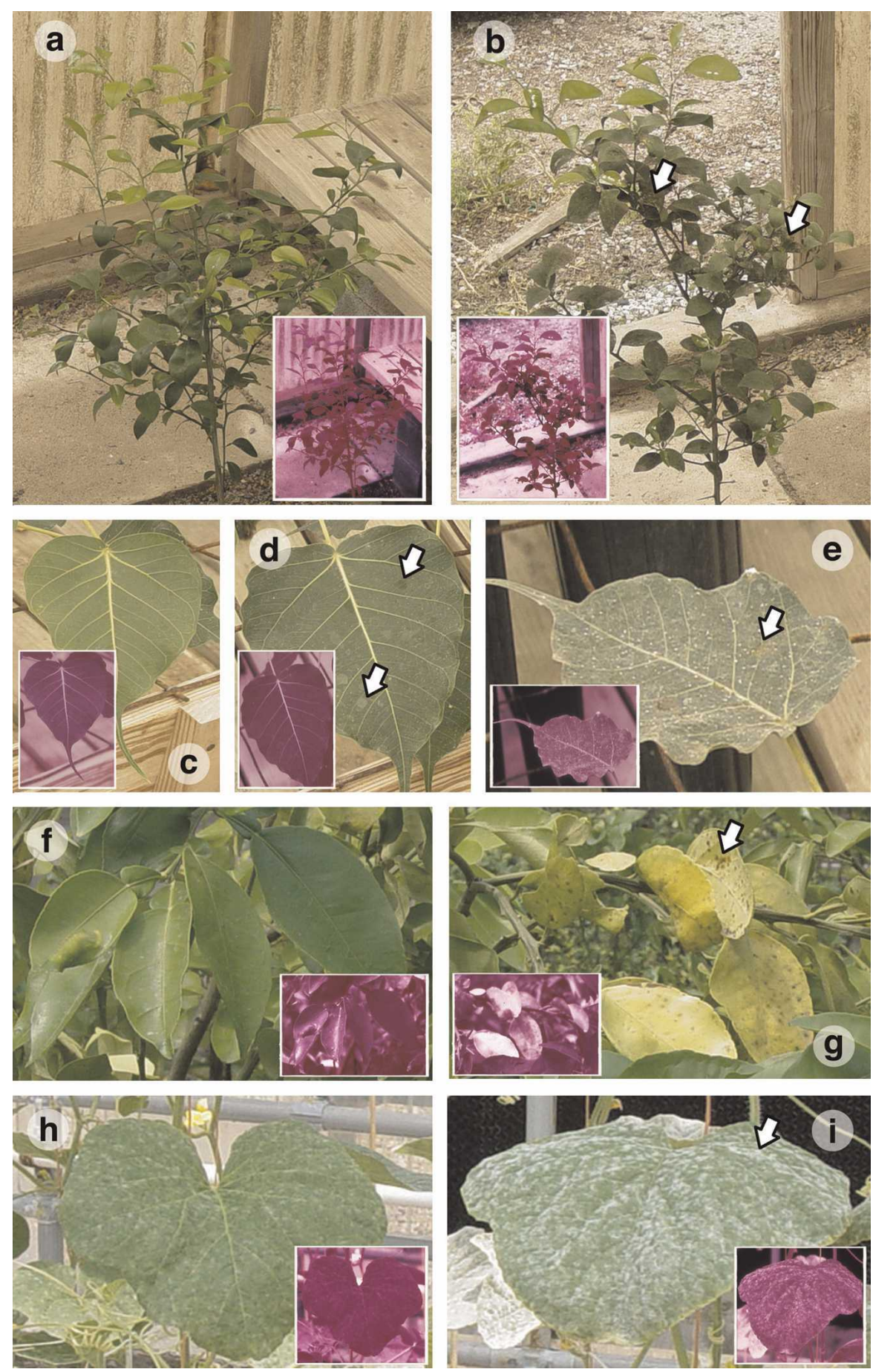

Fig. 1. Examples of color RGB and color infrared photographs (insets) of foliage acquired in a whole plant context and used to obtain near-infrared/red ratios. Sour orange: control (a) and sooty mold-infested (b; arrow); 'Bo' tree leaves: control (c), honeydew spotting (d; arrow), and sooty mold infested (e; arrow); grapefruit foliage: healthy control (f) and greasy spot disease (g; arrow); muskmelon leaves: low (h) and high (i; arrow) levels of powdery mildew disease.

were grown at the Texas A\&M UniversityKingsville Citrus Center (Weslaco, TX). Muskmelon (Cucumis melo) plants were grown at the Texas Agricultural Experiment Station (Weslaco, TX). "Control" cohorts were not infested with sooty mold, insects, or infected with pathogens. "Treatment" groups were naturally infested with sooty mold (Capnodium citri), insects, and infected with pathogens (Sphaerotheca fuliginea or
Mycosphaerella citri) under routine glasshouse-growing conditions.

Acquisition of spectral reflectance data and color infrared imagery. Spectral reflectance data were acquired from incident radiation reflected from foliage in a whole plant context and from individual leaves (see below) using a FieldSpec ${ }^{\circledR}$ VNIR spectroradiometer equipped with a remote cosine receptor (Analytical Spectral Devices [ASD],
Boulder, $\mathrm{CO}$ ). At the time of data collection, the instrument was optimized for ambient lighting conditions and a reflectance measurement was obtained from a white Spectralon ${ }^{\circledR}$ reference plate (ASD) to facilitate the conversion of radiance measurements (watts/ $\mathrm{m}^{2}$ ) to percent reflectance. Reflectance measurements were obtained using a target probe fitted with an $18^{\circ}$ instantaneous field of view adapter and data were processed using ViewSpecPro ${ }^{\circledR}$ software (ASD). CIR images of whole plant foliage and individual leaves were acquired using a conventional $35-\mathrm{mm}$ SLR camera (Nikon FE) (Nikon, Melville, NY) employing Kodak Ektachrome Infrared EIR film (Eastman Kodak, Rochester, NY) fitted with a 55-mm lens and a Wratten 15 yellow filter (Tiffen, Hauppage, NY). Conventional color (RGB) photographs were obtained using a digital camera (Sony Mavica $^{\circledR}$ 400) (Sony Electronics, San Diego, CA).

Color RGB and CIR images of whole plant foliage were obtained in situ from trifoliate orange, sour orange, 'Valencia' orange, and 'Bo' tree saplings within a glasshouse composed of yellow fiberglass (Figs. 1A-E). In situ reflectance data and images of muskmelon foliage were obtained under conventional frosted glass panels and grapefruit foliage was obtained under a plastic mesh screenhouse (Figs. 1F-I). For whole plant foliage data, a representative plant for each treatment was selected from a larger cohort of identically stressed plants for imaging.

Individual leaves were excised from saplings of each tree and immediately mounted between glass plates. Representative leaves exhibiting a range of infestations or symptoms were selected for comparison with healthy (control) leaves of the species examined in this study with the exception of C. melo (below). Spectral samples from each treatment consisted of multiple spectroradiometer readings (five) of 10 measurements each to obtain a mean of means. For C. melo, comparison was only made between healthy (control) and powdery mildew infected leaves in situ only. All photographs for a particular species were completed on the same day (26 Apr. 2005), under sunny conditions, between 1100 and $1700 \mathrm{HR}$.

For imaging, individual leaves were pressed between two glass plates $(0.3 \times 22$ $\times 30 \mathrm{~cm}$ ) to reduce the Gaussian curvature that is often associated with normal leaf structure and accentuated during stress (Nath et al., 2003). This was done to normalize reflectance values over the entire surface of the leaf so that measured differences are due to "treatment" and not leaf structure (Little et al., 2005). Leaves pressed between glass plates were mounted on a black, plastic plant growth flat filled with distilled water to absorb incident light and prevent background reflection in CIR images. These are subsequently referred to as "template images" and were obtained within a greenhouse composed of yellow fiberglass. For more information concerning the effect of different greenhouse materials on spectral reflectance data and 
CIR image acquisition, see Summy et al. (2004).

Analysis of spectral reflectance data and color infrared imagery. Reflectance measurements obtained from spectral curves of individual leaves [see previous use of the spectroradiometer (above)] were displayed and percent reflectance values at four wavelengths [blue $(450 \mathrm{~nm})$, green $(550 \mathrm{~nm})$, red $(650 \mathrm{~nm})$, and NIR $(850 \mathrm{~nm})]$ were recorded. The resulting reflectance data were analyzed parisons made, if appropriate, with Tukey's least significant difference (LSD) $(P<0.05)$ (Systat v.10; SPSS, 2000) (Table 1).

After processing, CIR images were converted to tagged image format (.TIF) files from slides; separated into green, red, and NIR wavebands; and imported into IDRISI32 $2^{\circledR}$ (Clark Laboratories, Worchester, MA). A simple vegetative index (NIR/red) was used as an "image ratio" to analyze CIR imagery. Approximately $20 \%$ of unrepresentative wavelengths was eliminated from with analysis of variance (ANOVA) and com-

derivative ratio images using contrast stretching. Contrast stretched derivative ratio images were layered with a stratified spatial sample of random points to compare healthy (control) and infected or infested regions of whole plant foliage or individual leaves. "Points" derived from derivative images each represent a ratio of NIR to red at a single pixel, which are generated by dividing the entire NIR band of a CIR image by its red band.

Twenty random points were chosen from the top seven internodes (if possible) of citrus plants examined for sooty mold development (Figs. 2-I, 2-II, and 2-III). Image subsamples were obtained from 'Bo' tree (Fig. 2-IV) and grapefruit (Fig. 2-V) images; 20 random points were selected from the outlined image subsamples in Figure 2-IV-g-i and Fig. 2-V-j and $\mathrm{k}$ (see also Table 2). Additionally, 20 random points were obtained from mature muskmelon leaf ratio images (Fig. 2-VI-1 and $\mathrm{m}$; Table 2). Therefore, $\mathrm{n}=20$ for each individual plant within an image (Fig. 2-I-

Table 1. Mean spectroradiometer reflectance data derived from individual leaves of greenhouse-reared plants infested with sooty mold, common insect pests, or infected with fungal pathogens.

\begin{tabular}{|c|c|c|c|c|c|}
\hline \multirow[b]{2}{*}{ Treatment } & \multirow[b]{2}{*}{ Figure } & \multicolumn{4}{|c|}{$\%$ reflectance } \\
\hline & & $\begin{array}{l}\text { Mean blue } \\
(450 \mathrm{~nm})\end{array}$ & $\begin{array}{c}\text { Mean green } \\
(550 \mathrm{~nm})\end{array}$ & $\begin{array}{l}\text { Mean red } \\
(650 \mathrm{~nm})\end{array}$ & $\begin{array}{l}\text { Mean near- } \\
\text { infrared } \\
(850 \mathrm{~nm})\end{array}$ \\
\hline \multicolumn{6}{|l|}{ Trifoliate orange (Poncirus trifoliata) } \\
\hline Control $(20 \mathrm{~d})^{\mathrm{z}}$ & $3-\mathrm{I}-\mathrm{a}$ & $2.8 \mathrm{c}^{\mathrm{y}}$ & $6.3 \mathrm{a}$ & $2.9 \mathrm{c}$ & $25.9 \mathrm{a}$ \\
\hline Control (35 d) & $3-\mathrm{I}-\mathrm{b}$ & $2.7 \mathrm{c}$ & $5.5 \mathrm{a}$ & $3.0 \mathrm{c}$ & $24.6 \mathrm{ab}$ \\
\hline Sooty old $^{\mathrm{x}}$ (intermediate) & $3-\mathrm{I}-\mathrm{c}$ & $2.7 \mathrm{c}$ & $5.1 \mathrm{a}$ & $3.7 \mathrm{bc}$ & $21.0 \mathrm{ab}$ \\
\hline Sooty mold (heavy) & $3-\mathrm{I}-\mathrm{d}$ & $4.0 \mathrm{a}$ & $6.5 \mathrm{a}$ & $5.5 \mathrm{a}$ & $19.3 \mathrm{ab}$ \\
\hline Sooty mold + mealy bug ${ }^{\mathrm{w}}$-infested & $3-\mathrm{I}-\mathrm{e}$ & $3.1 \mathrm{bc}$ & $5.0 \mathrm{a}$ & $3.9 \mathrm{bc}$ & $17.5 \mathrm{~b}$ \\
\hline Leaf minerv-infested & 3-I-f & $3.4 \mathrm{abc}$ & $5.5 \mathrm{a}$ & $3.4 \mathrm{bc}$ & $17.5 \mathrm{~b}$ \\
\hline Citrus mite ${ }^{u}$-infested & 3-I-g & $3.6 \mathrm{ab}$ & $6.1 \mathrm{a}$ & $4.0 \mathrm{~b}$ & $18.1 \mathrm{ab}$ \\
\hline \multicolumn{6}{|l|}{ Sour orange (Citrus aurantium) } \\
\hline Control (10 d) & 3-II-h & $2.5 \mathrm{c}$ & $12.7 \mathrm{a}$ & $3.7 \mathrm{~b}$ & $29.0 \mathrm{a}$ \\
\hline Control (20 d) & 3-II-i & $2.8 \mathrm{bc}$ & $6.9 \mathrm{~b}$ & $3.0 \mathrm{c}$ & $32.1 \mathrm{a}$ \\
\hline Control (35 d) & $3-\mathrm{II}-\mathrm{j}$ & $3.0 \mathrm{bc}$ & $5.6 \mathrm{~b}$ & $3.3 \mathrm{bc}$ & $24.9 \mathrm{ab}$ \\
\hline Sooty mold (light) & $3-\mathrm{II}-\mathrm{k}$ & $3.3 \mathrm{~b}$ & $5.4 \mathrm{~b}$ & $4.2 \mathrm{bc}$ & $19.9 \mathrm{bc}$ \\
\hline Sooty mold (intermediate) & 3-II-1 & $3.2 \mathrm{bc}$ & $5.1 \mathrm{bc}$ & $4.5 \mathrm{~b}$ & $14.3 \mathrm{~cd}$ \\
\hline Sooty mold (heavy, dark) & $3-\mathrm{II}-\mathrm{m}$ & $2.4 \mathrm{c}$ & $3.6 \mathrm{c}$ & $3.6 \mathrm{bc}$ & $9.0 \mathrm{~d}$ \\
\hline Sooty mold (heavy, tan) & $3-\mathrm{II}-\mathrm{n}$ & $4.5 \mathrm{a}$ & $6.5 \mathrm{~b}$ & $6.7 \mathrm{a}$ & $13.9 \mathrm{~cd}$ \\
\hline \multicolumn{6}{|l|}{ Valencia orange $(C$. sinensis $)$} \\
\hline Control $(20 \mathrm{~d})$ & 3-III-o & $3.2 \mathrm{c}$ & $11.0 \mathrm{a}$ & $4.0 \mathrm{~b}$ & $33.9 \mathrm{~b}$ \\
\hline Honeydew & 3-III-p & $3.9 \mathrm{~b}$ & $8.6 \mathrm{~b}$ & $4.5 \mathrm{~b}$ & $40.8 \mathrm{c}$ \\
\hline Sooty mold & 3 -III-q & $6.2 \mathrm{a}$ & $9.4 \mathrm{~b}$ & $10.0 \mathrm{a}$ & $16.7 \mathrm{a}$ \\
\hline \multicolumn{6}{|l|}{ Bo tree (Ficus religiosa) } \\
\hline Control & 3-IV-r & $3.5 \mathrm{a}$ & $6.5 \mathrm{a}$ & $3.6 \mathrm{a}$ & $33.9 \mathrm{a}$ \\
\hline Honeydew & $3-I V-s$ & $3.6 \mathrm{a}$ & $6.1 \mathrm{a}$ & $3.3 \mathrm{~b}$ & $34.5 \mathrm{a}$ \\
\hline Sooty mold & $3-I V-t$ & $3.8 \mathrm{a}$ & $5.6 \mathrm{a}$ & $4.1 \mathrm{a}$ & $26.1 \mathrm{~b}$ \\
\hline \multicolumn{6}{|l|}{ Grapefruit (C. paradisi) } \\
\hline Healthy control & $3-\mathrm{V}-\mathrm{u}$ & $2.7 \mathrm{c}$ & $15.6 \mathrm{c}$ & $4.4 \mathrm{~d}$ & $41.3 \mathrm{ab}$ \\
\hline Low greasy spot ${ }^{t}$ severity & $3-\mathrm{V}-\mathrm{V}$ & $4.1 \mathrm{bc}$ & $21.5 \mathrm{~b}$ & $9.2 \mathrm{c}$ & $38.3 \mathrm{~b}$ \\
\hline Intermediate greasy spot severity & $3-\mathrm{V}-\mathrm{w}$ & $5.5 \mathrm{~b}$ & $22.9 \mathrm{~b}$ & $11.5 \mathrm{~b}$ & $41.3 \mathrm{ab}$ \\
\hline High greasy spot severity & $3-V-x$ & $10.3 \mathrm{a}$ & $33.0 \mathrm{a}$ & $29.9 \mathrm{a}$ & $43.2 \mathrm{a}$ \\
\hline \multicolumn{6}{|l|}{ Muskmelon (Cucumis melo) } \\
\hline Control & 2-VI-1 & 4.4 & 11.7 & 4.0 & 52.1 \\
\hline Powdery mildew ${ }^{\mathrm{s}}$ & 2-VI-m & $5.6^{*}$ & 10.5 & $5.5^{*}$ & $38.9 *$ \\
\hline
\end{tabular}

${ }^{\mathrm{z}}$ Leaf age (in days).

${ }^{y}$ Each mean value is the average of spectral samples from each treatment consisted of multiple spectroradiometer readings (five) of 10 measurements each to obtain a mean of means. Values that are followed by different letters (within the same column for each plant species) differ significantly according to Tukey's least significant difference $(P<0.05)$; values followed by an asterisk differ significantly $(P<$ $0.05)$ from their respective control according to the Student's $t$ test.

${ }^{\mathrm{x}}$ Sooty mold [Capnodium spp. of fungi (and others spp.)].

${ }^{\text {w} M e a l y ~ b u g ~(P l a n o c o c c u s ~ c i t r i) . ~}$

"Leaf miner (Phyllocnistis citrella).

"Citrus mite (Eutetranuchus citri).

${ }^{\mathrm{t}}$ Greasy spot (Mycosphaerella citri).

'Powdery mildew (Sphaerotheca fuliginea).
III, VI-m and 1) or each image subsample (Fig. 2-IV-g-i and V-j and k).

For individual leaves mounted using the template system (described previously), 10 random points $(n=10)$ were selected from each leaf within each derivative ratio image (Figs. 3-I to 3-V). Random point means from image ratios were compared using Student's $t$ test $(P<0.05)$ or ANOVA and means separations (Tukey's LSD at $P<0.05$ ) (Systat v.10; SPSS, 2000) (Table 2). Only data from the same image (e.g., Fig. 3-I-a-g) were compared statistically.

\section{Results and Discussion}

The last Census of Horticultural Specialties (National Agricultural Statistics Service, 1998 ) indicated that $\approx 31.6$ million $\mathrm{ft}^{2}$ of greenhouse space was used to produce food crops with a wholesale value of $\$ 184.2$ million and an investment into the agricultural labor force of $\$ 3.6$ billion in the United States alone. In addition to this, much of the production of horticultural and landscaping transplants and vegetable and flower seeds occurs in large-scale glasshouse facilities.

Many studies have evaluated the acquisition of multispectral imagery as a tool to estimate yield responses and plant damage in the field (Yang and Everitt, 2002; Yang et al., 2005). However, very few have demonstrated the technical feasibility of using multispectral CIR imagery for detection of plant stress in the glasshouse (Summy et al., 2003, 2004; Summy and Little, 2005).

In this study, whole plant foliage and individual leaves that were infested with sooty mold and infected with fungal pathogens were imaged using conventional color [RGB; Figs. 1 and 3 (upper rows)] and CIR photography [CIR; Figs. 1 and 3 (middle rows)]. The resulting images were processed so that the NIR waveband of each CIR image was divided by its red waveband to obtain a simple vegetation index derivative image where each pixel represents a ratio of NIR to red [Figs. 2 and 3 (lower rows)]. High NIR and low red reflectance values are typical of healthy vegetation; thus, a ratio of these two values can be used as an indicator of plant status (Everitt et al., 1999). In addition, differences between healthy and stressed foliage can be accentuated and subtle differences more easily identified and analyzed using image ratios (Yousef et al., 2005).

Leaf age influences NIR/red ratio differences and this confounding factor may influence interpretation of whole plant foliage data acquired at close distances. To test the effect of leaf age on acquisition of NIR/red ratio data from CIR images, leaves of varying ages were compared using the template images (described in "Materials and Methods"). Twenty- and 35-d leaves from trifoliate orange did not differ in NIR $(850 \mathrm{~nm})$, red $(650 \mathrm{~nm})$, blue $(450 \mathrm{~nm})$, or green $(550$ $\mathrm{nm})$ reflectance values. In addition, there was no difference between NIR/red ratios or observable differences in the derivative ratio images (Table 2; Fig. 3-I). However, sour 

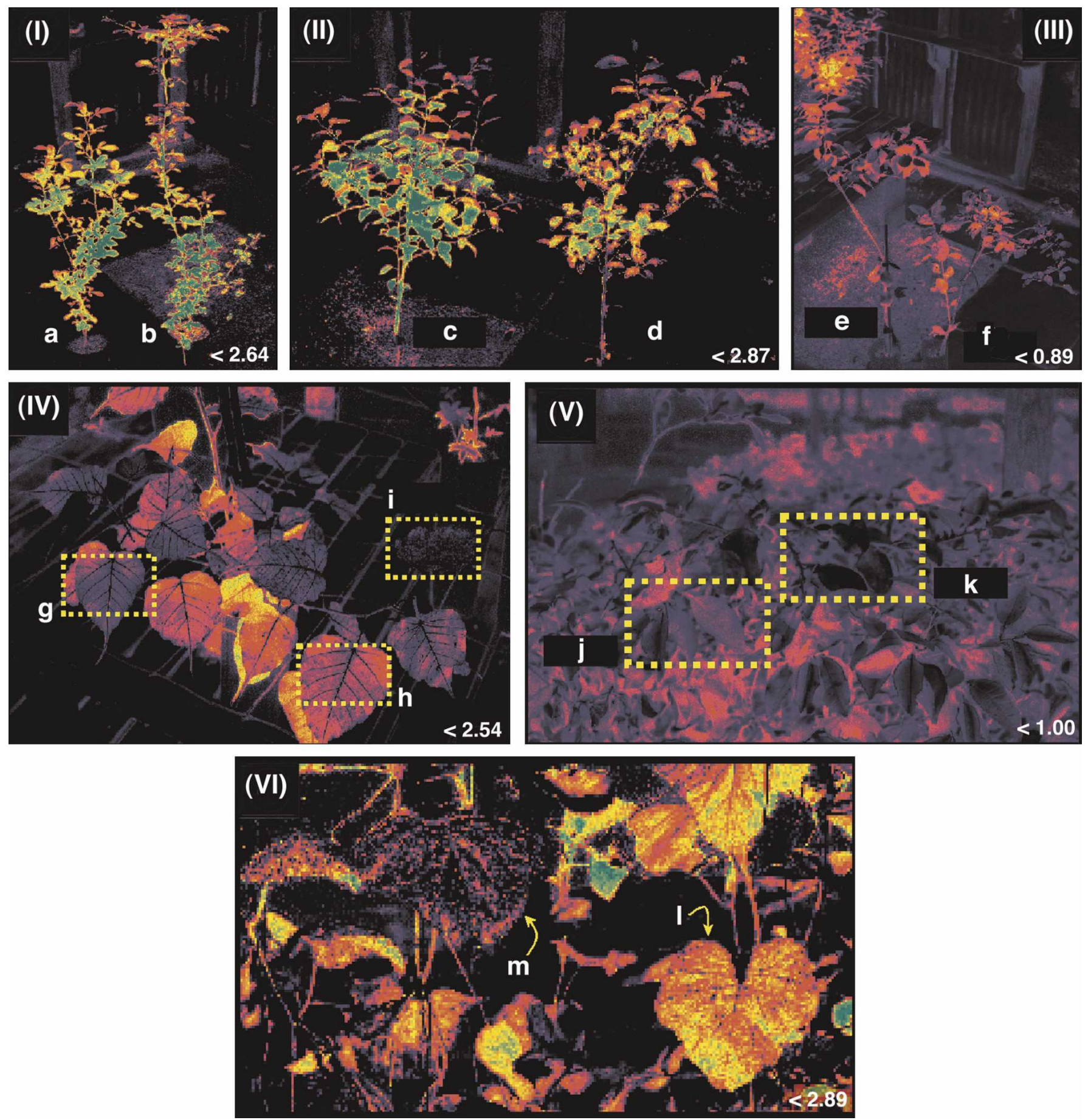

Fig. 2. Near-infrared/red ratio derivative images of whole trifoliate orange (I; Poncirus trifoliata), sour orange (II; Citrus aurantium), 'Valencia' orange (III; C. sinensis), 'Bo' tree (IV; F. religiosa), grapefruit (V; C. paradisi), and muskmelon (VI; Cucumis melo) plants. (I) Trifoliate orange saplings: uninfested control (a), infested with sooty mold (Capnodium citri spp. and other fungi), mealy bugs (Planococcus citri), leaf miners (Phyllocnistis citrella), and citrus mite (Eutetranuchus citri) (b); (II) sour orange saplings: uninfested control (c) and sooty mold infested (d); (III) 'Valencia' orange saplings: uninfested control (e) and sooty mold infested (f); (IV) 'Bo' saplings: uninfested leaf subsample (g), honeydew coated leaf subsample (h), and sooty mold infested leaf subsample (i) (see also Table 1 for data); (V) grapefruit saplings: subsample of noninfected leaves (j; see also Fig. 1F) and a subsample of leaves showing various levels of greasy spot (Mycosphaerella citri) severity (k; see also Fig. 1G); cantaloupe foliage: healthy mature leaf (1; see also Fig. 1H) and mature leaf infected with powdery mildew (Sphaerotheca fuliginea) hyphae and conidia (m; see also Fig. 1I). Images were contrast stretched (see lower right hand corner of each image) where necessary to eliminate unnecessary wavelengths. See also Tables 1 and 2 for spectrophotometric data and near-infrared/red ratios derived from derivative images of foliage in a whole plant context.

orange leaves that differed in ages from 10 to $35 \mathrm{~d}$ did not exhibit significantly different red or blue reflectance values, but the NIR/red ratio values and the resultant derivative images were significantly different (Table 2; Fig. 3-II).
This study showed that honeydew accumulation on 'Valencia' and 'Bo' tree leaves resulted in significant increases in NIR/red ratios (Table 2). In addition, the increased overall reflectance patterns are observable in derivative images (Figs. 3-III and 3-IV).
'Valencia' orange leaves were coated very evenly with insect honeydew (Fig. 3-III-p), whereas honeydew deposits on 'Bo' leaves were very spotty (Fig. 3-IV-s). This difference in distribution along the leaf surface may have contributed to differences in 
Table 2. Mean near-infrared (NIR)/red ratios derived from color infrared derivative images from whole plant foliage and individual leaves of greenhouse-reared plants infested with sooty mold, common insect pests, or infected with fungal pathogens.

\begin{tabular}{|c|c|c|}
\hline Treatment & Figure & Mean NIR/red ${ }^{2}$ \\
\hline \multicolumn{3}{|l|}{ Trifoliate orange (Poncirus trifoliata) } \\
\hline \multicolumn{3}{|l|}{ Whole plant } \\
\hline Control & $2-\mathrm{I}-\mathrm{a}$ & 5.78 \\
\hline Sooty mold ${ }^{y}+$ insect infestations & $2-\mathrm{I}-\mathrm{b}$ & $4.21 *$ \\
\hline \multicolumn{3}{|l|}{ Individual leaves } \\
\hline Control $(20 d)^{x}$ & $3-\mathrm{I}-\mathrm{a}$ & $10.20 \mathrm{a}$ \\
\hline Control (35 d) & $3-\mathrm{I}-\mathrm{b}$ & $9.50 \mathrm{ab}$ \\
\hline Sooty mold (intermediate) & $3-\mathrm{I}-\mathrm{c}$ & $7.79 \mathrm{~b}$ \\
\hline Sooty mold (heavy) & $3-\mathrm{I}-\mathrm{d}$ & $4.64 \mathrm{~d}$ \\
\hline Sooty mold + mealy bug ${ }^{\mathrm{w}}$-infested & $3-\mathrm{I}-\mathrm{e}$ & $6.20 \mathrm{~cd}$ \\
\hline Leaf miner ${ }^{\mathrm{v}}$-infested & $3-\mathrm{I}-\mathrm{f}$ & $7.58 \mathrm{c}$ \\
\hline Citrus mite ${ }^{\mathrm{u}}$-infested & $3-\mathrm{I}-\mathrm{g}$ & $5.74 \mathrm{~d}$ \\
\hline \multicolumn{3}{|l|}{ Sour orange (Citrus aurantium) } \\
\hline \multicolumn{3}{|l|}{ Whole plant } \\
\hline Control & 2-II-c & 4.63 \\
\hline Sooty mold & 2-II-d & $4.19 *$ \\
\hline \multicolumn{3}{|l|}{ Individual leaves } \\
\hline Control (10 d) & $3-\mathrm{II}-\mathrm{h}$ & $6.44 \mathrm{c}$ \\
\hline Control $(20 \mathrm{~d})$ & $3-\mathrm{II}-\mathrm{i}$ & $10.40 \mathrm{a}$ \\
\hline Control (35 d) & $3-\mathrm{II}-\mathrm{j}$ & $8.85 \mathrm{~b}$ \\
\hline Sooty mold (light) & $3-\mathrm{II}-\mathrm{k}$ & $7.54 \mathrm{bc}$ \\
\hline Sooty mold (intermediate) & 3-II-1 & $6.11 \mathrm{c}$ \\
\hline Sooty mold (heavy, dark) & 3-II-m & $3.05 \mathrm{~d}$ \\
\hline Sooty mold (heavy, tan) & 3-II-n & $2.69 \mathrm{e}$ \\
\hline \multicolumn{3}{|l|}{ Valencia orange (C. sinensis) } \\
\hline \multicolumn{3}{|l|}{ Whole plant } \\
\hline Control & 2-III-e & 6.27 \\
\hline Sooty mold & 2-III-f & $3.49 *$ \\
\hline \multicolumn{3}{|l|}{ Individual leaves } \\
\hline Control (20 d) & 3-III-o & $7.22 \mathrm{~b}$ \\
\hline Honeydew & 3-III-p & $8.72 \mathrm{c}$ \\
\hline Sooty mold & 3-III-q & $2.40 \mathrm{a}$ \\
\hline \multicolumn{3}{|l|}{ Bo tree (Ficus religiosa) } \\
\hline \multicolumn{3}{|l|}{ Whole plant } \\
\hline Control & 2-IV-g & $4.56 \mathrm{~b}$ \\
\hline Honeydew & $2-\mathrm{IV}-\mathrm{h}$ & $5.54 \mathrm{a}$ \\
\hline Sooty mold & 2-IV-i & $2.76 \mathrm{c}$ \\
\hline \multicolumn{3}{|l|}{ Individual leaves } \\
\hline Control & 3-IV-r & $6.26 \mathrm{~b}$ \\
\hline Honeydew & 3-IV-s & $7.90 \mathrm{a}$ \\
\hline Sooty mold & 3-IV-t & $5.21 \mathrm{~b}$ \\
\hline \multicolumn{3}{|l|}{ Grapefruit (C. paradisi) } \\
\hline \multicolumn{3}{|l|}{ Whole plant } \\
\hline Control & $2-V-j$ & 6.38 \\
\hline Greasy spot ${ }^{t}$ & $2-\mathrm{V}-\mathrm{k}$ & $2.70^{*}$ \\
\hline \multicolumn{3}{|l|}{ Individual leaves } \\
\hline Healthy control & $3-\mathrm{V}-\mathrm{u}$ & $6.43 \mathrm{a}$ \\
\hline Low greasy spot severity & $3-\mathrm{V}-\mathrm{v}$ & $4.01 \mathrm{~b}$ \\
\hline Intermediate greasy spot severity & $3-\mathrm{V}-\mathrm{w}$ & $2.89 \mathrm{c}$ \\
\hline High greasy spot severity & $3-\mathrm{V}-\mathrm{x}$ & $1.56 \mathrm{~d}$ \\
\hline \multicolumn{3}{|l|}{ Cantaloupe (Cucumis melo) } \\
\hline \multicolumn{3}{|l|}{ Whole plant } \\
\hline Control & $2-\mathrm{V}-1$ & 5.34 \\
\hline Powdery mildew ${ }^{\mathrm{s}}$ & $2-\mathrm{V}-\mathrm{m}$ & $3.90 *$ \\
\hline
\end{tabular}

${ }^{\mathrm{z}}$ Contrast stretched near-infrared/red ratio derivative images were layered with a stratified spatial sample of random points to compare "control" and "treatment" regions of plant foliage or individual leaves. For whole plant foliage near-infrared/red ratio data, 20 random points were chosen from the top seven internodes (if possible) of $P$. trifoliata, $C$. aurantium, and $C$. sinensis plants examined for sooty mold development; image subsamples were used for F. religiosa (Fig. 2-IV-g-i) and C. paradisi (Fig. 2-V-j and k). For C. melo, "control" and "treatment" regions (Fig. 2-V-l and 2-V-m, respectively) of plant foliage or individual leaves were compared. Values in columns followed by an asterisk differ significantly $(P<0.05)$ from their respective control according to the Student's $t$ test. For individual leaves (see Fig. 3), 10 points were randomly chosen from the stratified spatial sample. Values that are followed by different letters (within the same column for each plant species) differ significantly at $P<0.05$ using Tukey's least significant difference.

${ }^{\mathrm{y}}$ Sooty mold [Capnodium spp. of fungi (and others spp.)].

${ }^{\mathrm{x}}$ Leaf age (in days).

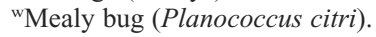

${ }^{\vee}$ Leaf miner (Phyllocnistis citrella).

"Citrus mite (Eutetranuchus citri).

${ }^{\mathrm{t}}$ Greasy spot (Mycosphaerella citri).

spowdery mildew (Sphaerotheca fuliginea). percent reflectance values in the NIR and red for the two tree species (Table 1).

Insect honeydew consists of a number of unique sugars that may not only contribute to sooty mold growth, but also the observed increase of NIR reflectance of honeydewcoated leaves in this study. The honeydew of scale insects and aphids is composed of large amounts of fructomaltose (Gray and Fraenkel, 1953). In addition, scale insect honeydew also contains several novel oligosaccharides that have tentatively been labeled as "stigmatriose," "stigmatetrose," and "stigmapentose" (Bogo, 2003). Whitefly (Bemesia spp.) honeydew is composed of bemisiose (a trisaccharide), trehalulose (a disaccharide), and a large portion of glucose (Byrne and Miller, 1990; Hendrix and Wei, 1994; Isaacs et al., 1998). Although sugar solutions tend to reflect greater amounts of NIR overall and only absorb light in limited portions of the NIR spectrum (800 to $1100 \mathrm{~nm}$ ) (Dull and Giangiacamo, 1984; Slaughter and Crisosto, 1998), it is not known if this is the underlying mechanism that accounts for greater NIR reflectance and subsequently increased NIR/ red ratios from honeydew-coated leaves.

Imagery of whole plant foliage infested with sooty mold consistently showed significant decreases in NIR/red ratio values when compared with healthy controls (Student's $t$, $P<0.05$; Table 2). Individual leaves covered with sooty mold absorbed a considerable amount of light compared with control leaves of the same age. For example, NIR reflectance $(850 \mathrm{~nm})$ from trifoliate orange leaves covered with intermediate and heavy levels of sooty mold reflected $85.4 \%$ and $78.5 \%$ of the $35 \mathrm{~d}$ control, respectively (Table 1), whereas sour orange leaves covered with light, intermediate, and heavy (dark and tan) levels of sooty mold reflected $79.9 \%, 57.4 \%$, $36.1 \%$, and $55.8 \%$ of NIR as the $35-\mathrm{d}$ control, respectively. Similar results were observed when comparing NIR reflectance of sooty molded 'Valencia' and 'Bo' tree leaves with their respective controls (Table 1). These consistent decreases in NIR led to consistent decreases in NIR/red ratio values because red reflectance values $(650 \mathrm{~nm}) \mathrm{did}$ not always decrease as sooty mold infestation increased (Table 2). In some cases, red reflectance actually increased significantly, as in the case of heavy sooty molds on trifoliate and sour orange leaves (Table 1). However, in all of these examples, derivative images of sooty molded leaves showed trends toward lower image ratio values as mold infestations manifested themselves (Figs. 3-I-IV).

The melanin content of dematiaceous fungal cell walls, which characterize sooty mold fungi, may be partially responsible for the large amounts of NIR absorption. Melanin is composed of indoles and tyrosine intermediates that normally function to absorb light and lend protection to irradiative damage in both fungi and animals (Riley, 1998). Bell and Wheeler (1986) and Babitskaya and Shcherba (2002) found that melanins extracted from dematiaceous ascomycetes and deuteromycetes exhibit absorption maxima in 

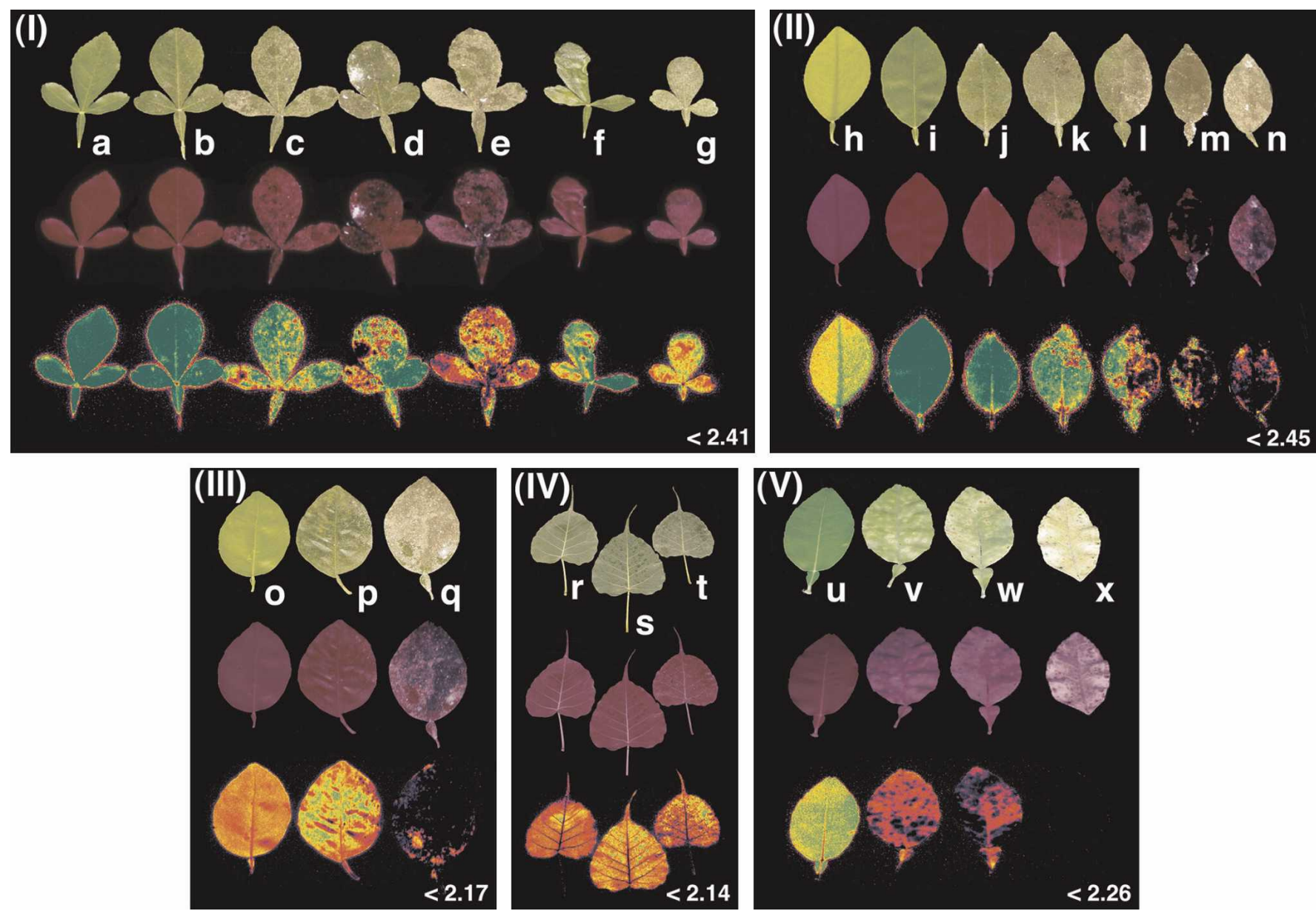

Fig. 3. Color RGB (top row of each figure), color infrared (middle row of each figure), near-infrared/red ratio derivative images (bottom row or each figure) of single plant leaves from trifoliate orange (I; P. trifoliata), sour orange (II; C. aurantium), 'Valencia' orange (III; C. sinensis), 'Bo' tree (IV; F. religiosa), and grapefruit (V; C. paradisi). (I) Trifoliate orange: 20 -d control (a), 35-d control (b), sooty molded (c), sooty mold + mealy bug (P. citri) infested (d-e), leaf miner (P. citrella) infested (f), and citrus mite (E. citri) infested (g); (II) sour orange: 10-d control (h), 20-d control (i), 35-d control (j), sooty mold (light) (k), sooty mold (intermediate) (1), sooty mold (heavy, dark) (m), and sooty mold (heavy, tan) (n); (III) 'Valencia' orange: greater than 15-d control (o), honeydew (p), and sooty mold (q); (IV) 'Bo' tree: control (r), honeydew (s), and sooty mold (t); grapefruit: control (healthy) (u), greasy spot (M. citri) [low (v), intermediate $(\mathrm{w})$, and high disease severity $(\mathrm{x})]$. Image backgrounds were masked for purposes of visual clarity; data were acquired before masking. Images were contrast stretched (see lower right hand corner of each image) where necessary to eliminate unnecessary wavelengths. See also Tables 1 and 2 for spectrophotometric data and near-infrared/red ratios derived from derivative images of individual leaves.

wavelength ranges of 300 to $400 \mathrm{~nm}$ (ultraviolet), 600 to $700 \mathrm{~nm}$ (red), and 700 to 900 nm (NIR).

In this study, symptoms and signs of two foliar fungal pathogens were imaged under glasshouse conditions, including a common powdery mildew of cucurbits (Sphaerotheca fuliginea) and the greasy spot pathogen of citrus (Mycosphaerella citri). M. citri is a foliar pathogen of citrus that causes significant amounts of chlorosis in leaves as part of the disease process. Chlorosis discolors citrus leaves as large numbers of fungal pseudothecia are produced (Mondal and Timmer, 2006). In this disease, as severity increases, red reflectance from the chlorotic portions of affected leaves increases appreciably, but NIR reflectance does not change significantly (Table 1). Because of the relatively steady NIR values, there is a concomitant decrease in the NIR/red ratios (Table 2). Thus, in Fig. $3-\mathrm{V}-\mathrm{x}$, the average $\mathrm{NIR} /$ red ratio (1.56), for high greasy spot severity, was coded as black in the derivative image because the image was contrast stretched (less than 2.26) to remove background noise (e.g., unnecessary wavelengths; see "Materials and Methods").

In the case of the powdery mildew fungus, $S$. fuliginea, leaves are not discolored by chlorosis, but the adaxial surfaces are covered with hyphal growth and numerous conidia. This gives the surface of the leaf a "powdery" appearance (Little, 2004). In some ways, this situation is comparable to the sooty mold examples discussed earlier with the exception that the fungal growth on the surface of the leaf appears white instead of tan, brown, or black. In the case of the cucurbit powdery mildew, NIR/red ratios were significantly reduced as a result of decreased levels of NIR reflectance and increased red reflectance (Tables 1 and 2; Fig. 2-VI). It is hypothesized that incident radiation coming into contact with the hyaline fungal structures on the surface of the leaf is both scattered and absorbed. The random growth of conidiophores on the leaf surface produces an infinite number of angles, which reflect light, thus causing scatter- ing. In addition, the numerous water droplets that are trapped between hyphae and conidiophores covering the leaf will act to absorb light.

In this study, changes in NIR and red reflectance, and a CIR image enhancement technique, the NIR/red ratio (simple vegetation index), have provided a mechanism to differentiate between healthy and stressed plants. Although similar trends have been observed using field-level airborne remote sensing, this is the first study, to our knowledge, which differentiates plant stress resulting from sooty mold and fungal pathogens using such image analysis techniques under a glasshouse setting. Additionally, the comparison of whole plant foliage with individual leaves mounted on a template has proven to be a valuable experimental tool to differentiate component reflectances that contribute to the identification of overall differences between healthy and stressed hosts.

Practical uses and the adoption of such image analysis technology in the large-scale greenhouse setting will depend on several factors. The application must be: 1) effective 
(the technology must accurately differentiate between healthy and stressed plants under diverse conditions), 2) inexpensive (acquisition of CIR images must be performed with inexpensive CIR cameras with digital charge coupled devices), and (3) user-friendly (on-site software processing with an easily interpreted interface). Our results suggest a considerable potential for identification of honeydew, sooty mold (and concurrent feeding insect infestations) as well as fungal foliar diseases.

\section{Literature Cited}

Babitskaya, V.G. and V.V. Shcherba. 2002. The nature of melanin pigments of several microand macromycetes. Appl. Biochem. Microbiol. $38: 247-251$.

Bell, A.A. and M.H. Wheeler. 1986. Biosynthesis and function of fungal melanins. Ann. Rev. Phytopathol. 24:411-451.

Blazquez, C.H., O. Lowe, J.R. Sisk, and M.D. Bilbrey. 1988. Use of aerial color infrared photography, dual color video, and a computer system for property appraisal of citrus groves. Photogramm. Eng. Rem. Sens. 51:233236.

Bogo, A. 2003. New group of oligosaccharides excreted in honeydew from scale insects Stigmacoccus $\mathrm{sp}$. and Coccus hesperidum L. Ciénc. Rural 33:593-599.

Brenchley, G.H. 1964. Aerial photography for the study of potato blight. World Rev. Pest Contr. 3:68-84.

Byrne, D.N. and W.B. Miller. 1990. Carbohydrates and amino acid composition of phloem sap and honeydew produced by Bemesia tabaci. J. Insect Physiol. 36:433-439.

Chase, A.R. 1987. Compendium of ornamental foliage plant diseases. APS Press, St. Paul, MN.

Colwell, R.N. 1956. Determining the prevalence of certain cereal diseases by means of aerial photography. Hilgardia 26:223-286.

Daughtrey, M.L., R.L. Wick, and J.L. Peterson. 1995. Compendium of flowering potted plant diseases. APS Press, St. Paul, MN.

Drees, B.M. and J.A. Jackman. 1998. A field guide to common Texas insects. Gulf Publishing, Lanham, MD.

Dull, G.G. and R. Giangiacamo. 1984. Determination of individual simple sugars in aqueous solution by near infrared spectrophotometry. J. Food Sci. 49:1601-1603.

Everitt, J.H., D.E. Escobar, D.N. Appel, W.G. Riggs, and M.R. Davis. 1999. Using airborne digital imagery for detecting oak wilt disease. Plant Dis. 83:502-505.

Everitt, J.H., D.E. Escobar, K.R. Summy, M.A. Alaniz, and M.R. Davis. 1996. Using spatial information technologies for detecting and mapping whitefly and harvester ant infestations in south Texas. Southwest. Entomol. 21:421432.

Everitt, J.H., D.E. Escobar, K.R. Summy, and M.R. Davis. 1994. Using airborne video, global positioning system, and geographic information system technologies for detecting and mapping citrus blackfly. Southwest. Entomol. 19:129-138.

Everitt, J.H., A.H. Gerbermann, and M.A. Alaniz. 1981. Microdensitometry to identify saline rangelands on $70 \mathrm{~mm}$ color infrared film. Photogramm. Eng. Rem. Sens. 47:1357-1362. Farr, D.F., G.F. Bills, G.P. Chamuris, and A.Y. Rossman. 1989. Fungi on plants and plant products in the United States. APS Press, St. Paul, MN.

Gray, H.E. and G. Fraenkel. 1953. Fructomaltose, a recently discovered trisaccharide isolated from honeydew. Science 118:303-305.

Hart, W.G., S.J. Ingle, M.R. Davis, and C. Magnum. 1973. Aerial photography with infrared color film as a method of surveying for citrus blackfly. J. Econ. Entomol. 66:190-194.

Hart, W.G. and V.I. Myers. 1968. Infrared aerial color photography for the detection of populations of brown soft scale in citrus groves. J. Econ. Entomol. 61:617-624.

Hendrix, D.L. and Y. Wei. 1994. Bemesiose: An unusual trisaccharide in Bemesia honeydew. Carb. Res. 253:329-334.

Isaacs, R., D.N. Byrne, and D.L. Hendrix. 1998. Feeding rates and carbohydrate metabolism by Bemesia tabaci (Homoptera: Aleyrodidae) on different quality phloem saps. Physiol. Entomol. 23:241-248.

Jones, J.B., J.P. Jones, R.E. Stall, and T.A. Zitter. 1991. Compendium of tomato diseases. APS Press, St. Paul, MN.

Little, C.R. 2004. Sphaerotheca fuliginea (cucurbit powdery mildew). American Phytopathological Society publication number: IW000036. 10 May 2006. <http://www.apsnet.org/online/ Archive/2004/IW000047.asp>.

Little, C.R., D.L. Hinojosa-Kettelkamp, J. Carter, A.M. Vasquez, S. Yousef, and K.R. Summy. 2005. A technique to facilitate accurate spectral measurements and color infrared imagery of individual excised leaves. In: Proceedings of the 20th Biennial Workshop on Color Photography \& Videography and Airborne Imaging for Resource Assessment, American Society for Photogrammetry and Remote Sensing, Weslaco, TX (CD-ROM).

Mondal, S.N. and L.W. Timmer. 2006. Greasy spot, a serious endemic problem for citrus production in the Caribbean basin. Plant Dis. 90:532-538.

Myers, V.I., L.R. Ussery, and W.J. Rippert. 1963. Photogrammetry for detailed detection of drainage and salinity problems. Am. Soc. Agr. Eng. 6:332-334.

Nath, U., B.C.W. Crawford, R. Carpenter, and E. Coen. 2003. Genetic control of surface curvature. Science 299:1404-1407.

National Agricultural Statistics Service. 1998. Census of horticultural specialties. Agricultural Statistics Board, U.S. Department of Agriculture, Washington, DC.

Norman, G.G. and N.L. Fritz. 1965. Infrared photography as an indicator of disease and decline in citrus. Fla. St. Hort. Soc. Proc. 75:59-63.

Payne, J.A., W.G. Hart, M.R. Davis, L.S. Jones, D.J. Weaver, and B.D. Horton. 1971. Detection of peach and pecan pests and diseases with color infrared aerial photography, p. 216-230. In: Proceedings of the 3rd Biennial Workshop on Color Aerial Photography in the Plant Sciences, Church Falls, VA. American Society of Photogrammetry.

Reynolds, D.R. 1999. Capnodium citri: The sooty mold fungi comprising the taxon concept. Mycopathologia 148:141-147.
Riley, P.A. 1998. Melanin. Int. J. Biochem. Cell Biol. 29:1235-1239.

Slaughter, D.C. and C.H. Crisosto. 1998. Nondestructive internal quality assessment of kiwifruit using near-infrared spectroscopy. Sem. Food Anal. 3:131-140.

SPSS. 2000. Systat 10 statistics. Vol. I. SPSS, Inc., Chicago, IL.

Summy, K.R. and C.R. Little. 2005. Detection of stressors in glasshouse crops using color infrared imagery: I. Damage caused by fungal pathogens and sooty mold. In: Proceedings of the 20th Biennial Workshop on Aerial Photography, Videography, and High Resolution Digital Imagery for Resource Assessment, American Society for Photogrammetry and Remote Sensing, Weslaco, TX (CD-ROM).

Summy, K.R., C.R. Little, R.A. Mazariegos, J.H. Everitt, and M.R. Davis. 2004. Technical feasibility of color infrared imagery for monitoring physiological stress in selected glasshouse crops. In: Proceedings of the 19th Biennial Workshop on Color Photography \& Videography and Airborne Imaging for Resource Assessment, American Society for Photogrammetry and Remote Sensing, Logan, UT (CD-ROM).

Summy, K.R., C.R. Little, R.A. Mazariegos, J.H. Everitt, M.R. Davis, J.V. French, and A.W. Scott. 2003. Detecting stress in glasshouse plants using color infrared imagery: A potential new application for remote sensing. Subtrop. Plant Sci. 55:51-58.

Summy, K.R., C.R. Little, R.A. Mazariegos, R. Valdez, D.L. Hinojosa-Kettelkamp, J. Carter, and S. Yousef. 2005. Evaluation of artificial lighting sources for the acquisition of color infrared imagery under glasshouse conditions. Subtrop. Plant Sci. 56:44-51.

Texas Agricultural Experiment Station. 1988. Texas plant disease handbook. Texas Agricultural Extension Service, Texas A\&M University System, Publication 2M-4-88, Revision.

Thomas, J.R. and G.F. Oerther. 1977. Estimation of crop conditions and sugar cane yields using photography. Amer. Soc. Sugar Cane Technol. Proc. 6:93-99.

Timmer, L.W., S.M. Garnsey, and J.H. Graham. 2000. Compendium of citrus diseases. 2nd Ed. APS Press, St. Paul, MN.

Toler, R.W., D.B. Smith, and J.C. Harlan. 1981. Use of aerial color infrared photography to evaluate crop disease. Plant Dis. 75:24-31.

Yang, C. and J.H. Everitt. 2002. Relationships between yield monitor data and airborne multidate multispectral imagery for grain sorghum. Prec. Agr. 3:373-388.

Yang, C., C.J. Fernandez, and J.H. Everitt. 2005. Mapping Phymatotrichum root rot of cotton using airborne three-band digital imagery. T. Amer. Soc. Agr. Eng. 48:1619-1626.

Yousef, S., K.R. Summy, C.R. Little, A. Kuang, H.R. DeYoe, and J.H. Everitt. 2005. Detection of stressors in glasshouse crops using color infrared imagery: III. Effects of salt toxicity and nitrogen deficiency. In: Proceedings of the 20th Biennial Workshop on Color Photography \& Videography and Airborne Imaging for Resource Assessment, American Society for Photogrammetry and Remote Sensing, Weslaco, TX (CD-ROM).

Zitter, T.A., D.L. Hopkins, and C.E. Thomas. 1996 Compendium of cucurbit diseases. APS Press, St. Paul, MN. 